\title{
The feasibility of alternative dispute resolution to resolve intellectual property disputes in Jordan
}

\author{
Bashar H. Malkawi*
}

\section{Background}

Before the rise of Islam there was no formal judicial system. Disputes which arose between the members of a tribe were customarily settled by referring the disputes to the leader of the tribe. ${ }^{1}$ In resolving disputes, the leader typically resorted to amicable means, including mediation. The leader endeavoured to reach a solution of a particular dispute in such a way as to maintain solidarity among his people on the one hand and to maintain his honourable position on the other. ${ }^{2}$ Moreover, because of the commercial and trading relations among these Arab tribes, all parties found it necessary to conduct dealings and to settle disputes arising out of those dealings in a flexible manner. Accordingly, certain forms of conciliation or mediation and arbitration came to be known and were applied by these tribes since early times.

As the rise of Islam was accompanied by a call for peace, it was only natural for Islam to call for settlement of disputes in an amicable manner. Sharia includes express provisions relating to amicable settlement of disputes. ${ }^{3}$ The Qur'an states:

if ye fear a breach between them twain (i.e. husband and wife), then appoint (two) arbiters, one from his family, and the other from hers; if they wish for peace, God will cause their conciliation; for God hath full knowledge, and is acquainted with all things. ${ }^{4}$

The Prophet himself resorted to arbitration in his conflict with the tribe of Banu Qurayza. Muslim rulers subsequently followed his example, notably in the disastrous arbitration between Muawiyah (the governor of Syria) and the Caliph Ali (the Prophet's son-in-law) in

\footnotetext{
Email: bmalkawi@sharjah.ac.ae. The author would like to thank Professor David A. Gantz for his guidance. Additional thanks to the editor of JIPLP, editorial staff and the two expert referees for their advisement and insights into this article.

1 See Faisal Kutty 'The Shari'a Factor in International Commercial Arbitration' (2006) 28 Loyola LA Int'l and Comp L Rev 565, 589-90.

2 Ibid.

3 The law in Islam may be thought of as being composed of at least two parts: revealed and non-revealed. The revealed form of Shari'a has two proper sources: the Qur'an (the holy book) and the sunna (traditions based on the hadith, sayings and actions of the prophet). Non-revealed sources of Shari'a, developed by Muslim jurists after the revelation of the Qur'an and the sunna, include ijma (consensus of Muslim scholars on a point of law) and qiyas (a sub-ijtihad species of strict analogical
}

\section{The author}

- Bashar H. Malkawi is Associate Professor of Law at the University of Sharjah, United Arab Emirates.

\section{This article}

- The purpose of this article is to examine the feasibility and working of the conciliatory means for settlement of intellectual property disputes in Jordan. Arbitration is the principal mechanism used.

- This article discusses two specific issues relating to the use of alternative dispute resolution (ADR) for the resolution of intellectual property disputes: the reasons why an owner or user of intellectual property rights might prefer to resolve disputes concerning those rights by means of ADR and whether disputes involving intellectual property rights are arbitrable.

- My discussion of the first issue is not specific to any particular country. However, discussion of the second issue reports on the state of the law in Jordan as a case study for other Arab countries.

659 AD. Another example was the Treaty of Medina of $622 \mathrm{AD}$, a security pact among the city's residents, which called for arbitration of any disputes by the Prophet Muhammad. ${ }^{5}$ One may say that amicable

reasoning). These are the authoritative sources of jurisprudence (usul al-fiqh). See Raj Bhala 'Theological Categories for Special and Differential Treatment' (2002) 50 U Kan L Rev 635, 680; John Walbridge 'Logic in the Islamic Intellectual Tradition: The Recent Centuries' (2000) 39(1) Islamic Stud. 55, 68.

4 Qur'an 4:35.

5 Charles N Brower and Jeremy K Sharpe 'International Arbitration and the Islamic World: The Third Phase (2003) 97 AJIL 643; S Breckenridge Thomas 'International Arbitration: A Historical Perspective and Practice Guide Connecting Four Emerging World Cultures: China, Mexico, Nigeria, and Saudi Arabia' (2006) 17 Am Rev Int'l Arb 183, 206-12; Joshua F Berry 'The Trouble We Have with the Iraqis is US: A Proposal for Alternative Dispute Resolution in the New Iraq' (2005) 20 Ohio St J on Disp Resol 487, 504. 
means of settlement of disputes, particularly commercial disputes, are deeply rooted in Muslim and Arab traditions and have long been implemented in practice.

Despite references to amicable means of settling disputes in Sharia and what social norms would otherwise suggest, resort to the courts in Arab countries is currently popular. ${ }^{6}$ Courts are used to settle a myriad of cases involving property, marriage, landlord-tenant, commerce, and labour issues. ${ }^{7}$ In some cases, people prefer to bring an action before the courts as part of a bargaining strategy to obtain concessions from parties to a case. ${ }^{8}$ Courts in Arab countries refuse to dismiss frivolous or inappropriate cases, as compared to the United States. ${ }^{9}$ Easy access to courts with lower fees for case registration and lower attorney fees contribute to court overload in Arab countries. ${ }^{10}$ In addition, the number of lawyers in Arab countries has been increasing in recent years. A country that has a high number of lawyers is inclined to be more litigious. Given these factors, it seems safe to state that Arab societies are litigious, perhaps as litigious as US society.

The purpose of this article is to examine the feasibility and working of the conciliatory means of settlement of intellectual property disputes in Jordan. While there are multiple forums for resolving disputes, the principal mechanism this article is concerned with is arbitration-the most commonly used method associated with business and commercial disputes. Dispute settlement mechanisms can be broadly divided into binding and non-binding procedures and hybrids. Arbitration is the private, non-judicial adjudication of a commercial dispute, usually by a panel of one or three private arbitrators appointed by the parties, which results in a binding outcome. ${ }^{11}$

Other dispute settlement mechanisms include mediation. Mediation is the process by which a neutral third party assists disputing parties in reaching a voluntary resolution of their dispute. ${ }^{12}$ Med-arb and mini-trials are yet other examples of dispute settlement mechan-

6 Rosa María González Tirados 'Negotiation. An A-Z Guide' (2010) 48 Management Decision 1023, 1025 (Arabs prefer to establish personal relations and resolve issues through mediation or continued negotiation).

7 Nathan J Brown The Rule of Law in the Arab World: Courts in Egypt and the Gulf (Cambridge University Press Cambridge 1997) 190, 196.

8 This is accomplished through the use of claims and counter-claims. Ibid, 218.

9 Ibid, 191.

10 Ibid.

11 Benjamin F Tennille, Lee Applebaum and Anne Tucker Nees 'Getting to Yes in Specialized Courts: The Unique Role of ADR in Business Court Cases' (2010) 11 Pepp Disp Resol LJ 35, 49 (2010).

12 The main feature of mediation, as opposed to court suit and arbitration, is its lack of any means of compulsion. Sets of rules play a fundamentally limited role in mediation compared to binding arbitration. Ibid, 48-49. See Mark D Bennett and Scott Hughes The Art of Mediation (2nd edn South Bend, Indiana NITA 2005) 9-13. isms. Med-arb combines the elements of mediation and arbitration, such that a neutral and impartial third party serves as a mediator, but if the parties are unable to agree to a settlement, the third party takes on the arbitrator role. In mini-trials, the parties select and then provide the neutral advisor with background information and briefs that will be presented. ${ }^{13}$ This process indicates the strengths and weaknesses of each party's case and the likelihood of settling the dispute. Collectively, these forms are known as alternative dispute resolution (ADR) - an umbrella term used to encompass a wide variety of practices.

This article discusses two specific issues relating to the use of ADR for the resolution of intellectual property disputes: (1) the reasons why an owner or user of intellectual property rights might prefer to resolve disputes concerning those rights by means of ADR; and (2) whether disputes involving intellectual property rights are arbitrable. My discussion of the first issue is not specific to any particular country. However, discussion of the second issue reports on the state of the law in Jordan.

\section{Why consider ADR for intellectual property disputes?}

As a general principle, intellectual property rights are territorial in scope. The right in each country is determined by the law of that country and is independent of equivalent rights governing the same subject matter such as an invention or trade mark in other countries. ${ }^{14}$ In addition, courts generally refuse to apply the patent and copyright statutes to conduct abroad. ${ }^{15}$ Although Jordan's intellectual property laws are not explicit on this issue, it is understood that these laws do not apply beyond the country's borders. ${ }^{16}$ In contrast, licensing contracts concerning intellectual property extend rights and obligations beyond a single nation's

13 Douglas A Henderson 'Avoiding Litigation with the Mini-Trial: The Corporate Bottom Line As Dispute Resolution Technique' (1995) 46 SC L Rev 237, 240-41.

14 William R Cornish, David Llewelyn and Tanya Aplin Intellectual Property: Patents, Copyright, Trademark and Allied Rights (7th edn Sweet and Maxwell London 2010) 35.

15 Curtis A Bradley 'Territorial Intellectual Property Rights in an Age of Globalism' (1997) 37 Va J Int'l L 505, 514 and 520 (The Supreme Court has stated that US courts are to presume that legislation of Congress, unless a contrary intent appears, is meant to apply only within the territorial boundaries of the United States. The Court has articulated at least five justifications for this presumption: international law, international comity, choice-of-law principles, likely congressional intent and separation-of-powers considerations).

16 Patent Law of Jordan No 32 of 1999 as amended by Law No 71 of 2001, art 21, Official Gazette No 4520 (2001); Copyright Law of Jordan No 22 of 1992 as amended by Law No 52 of 2001, art 8, Official Gazette No 4508 (2001). 
territorial boundaries. ADR offers parties a range of valuable advantages over litigation. An owner of intellectual property may use ADR to settle an intellectual property case for many of the same advantages or reasons that ADR generally offers in non-intellectual property cases.

The first advantage relates to certainty. Intellectual property licensing contracts generally involve parties from different countries. These contracts may involve the laws and courts of several countries, which creates ambiguity in terms of the governing law and proper jurisdiction. ${ }^{17}$ Accordingly, one of the primary reasons for including a contractual clause mandating ADR rather than litigation of any intellectual property dispute is to provide the parties with the certainty that, in the event of a dispute, they will be submitting their dispute to a single forum for resolution rather than potentially to several different forums in different jurisdictions. Without such an arbitration provision in the contract, one party may file a lawsuit in each of the several different jurisdictions having power to apply its laws to the parties or contract at hand.

Arbitration and other ADR mechanisms tend to provide speedier resolutions of disputes than going through litigation in courts. ${ }^{18}$ This typically occurs either because arbitration and ADR proceedings are able to commence without delay or because of the flexibility in administering arbitration and other ADR proceedings. ${ }^{19}$ The speed of dispute resolution is an important consideration when it involves intellectual property rights. The reason for this is that court litigation can take much longer than the period of protection for the product involved. For example, if the dispute concerns a patent, which is protected for a maximum period of twenty years, court proceedings can last five years, thus

17 See Graeme B Dinwoodie 'Developing A Private International Intellectual Property Law: The Demise of Territoriality?'(2009) 51 Wm \& Mary L Rev 711, 723.

18 Aaron Pereira 'Licensing Technology to the Brics: The Case for ADR' (2009) 11 Cardozo J Conflict Resol 235, 246. (Businesses need to know when a dispute is likely to be decided to determine whether they can build a new plant, market their new drug, or find other ways to generate profit. Business people often simply cannot afford to wait for traditional litigation, especially international litigation, and therefore opt for ADR.)

19 Richard Hill 'The Theoretical Basis of Mediation and Other Forms of ADR: Why They work' (1998) 14 Arb Int'l 174, 182.

20 On average, an intellectual property case in Jordan takes about four to five years to decide: Jordanian Judicial Council Annual Report on Court Cases for the Year 2011 (Judicial Council Amman 2011) 65-68. In the USA, cases involving computer software disputes, for example, can result in a litigation process that takes longer than the life-cycle of the relevant product itself, invariably resulting in damages being awarded too late: Christian Burhring-Uhle Arbitration and Mediation in International Business (Kluwer Law International The Hague 1996) 313.

21 Litigation costs are so high because litigation is a highly competitive and adversarial process that encourages the parties to exaggerate their claims: Michael J Meurer 'Controlling Opportunistic and Anti-Competitive rendering the case useless or reducing the patent's lifespan and affecting the patent holder's profitability. ${ }^{20}$

Arbitration and other ADR mechanisms can significantly reduce the costs of settlement. Typical intellectual property litigation often spans several years with attorney fees and damage awards commonly in hundreds of millions of dollars. Studies indicate that litigating a patent case costs two to five million US dollars. ${ }^{21}$ Copyright and trade mark cases tend to cost somewhat less than patent cases because they are less technical. Although arbitrators' fees can be quite high, the overall costs are usually lower because arbitration is in general a shorter process than litigation. ${ }^{22}$ Thus there are cost savings associated with arbitration and other ADR mechanisms when compared to litigation.

The comparative advantage of ADR mechanisms is neutrality at least in the sense of not being affiliated with a particular nation. ${ }^{23}$ The valuable aspect of ADR's neutrality is the ability of arbitration and mediation to accommodate significantly different legal and commercial practices and expectations, as often exist when the parties to the transaction are from both Western and non-Western traditions. The arbitrator or mediator, as an independent third party to the dispute, is there to assist the parties to communicate with each other in a rational manner, identify disputed issues, consider available options and reach a decision or settlement that is fair and equitable to all parties.

Intellectual property disputes often involve proprietary know-how with respect to a patented invention or a trade secret with other proprietary information. Bringing a lawsuit in a public court of law against a trade secret infringer presents a risk of losing the confidentiality of that trade secret and its value. ${ }^{24}$ For example, trade secret owners may disclose information

Intellectual Property Litigation' (2003) 44 BC L Rev 509, 516; Murray Lee Eiland 'The Institutional Role in Arbitrating Patent Disputes' (2009) 9 Pepp Disp Resol LJ 283, 284-85; Mark A Glick, Lara A Reymann and Richard R Hoffmann Intellectual Property Damages: Guidelines and Analysis (John Wiley \& Sons Hoboken, NJ 2002) 20 (the trial stage costs each side approximately US \$2 million in legal fees and related expenses, and that average litigation costs continue to increase by up to 15 per cent each year). The cost to litigate patents in the European Union would be more than one million Euro at the trial level and a similar amount at the appellate level: European Patent Office 'Assessment of the Impact of the European Patent Litigation Agreement (Epla) On Litigation Of European Patents', EPO.org, February 2006, 10-11.

22 John Yukio Gotanda 'Setting Arbitrators' Fees: An International Survey' (2000) 33 Vand J Transnat'l L 779, 785-789 (most arbitrators base their fees on the amount of work performed, except when an arbitral institution, such as the ICC, sets their fees based on a percentage of the amount in dispute).

23 Rebecca Hollander-Blumoff and Tom R Tyler 'Fostering Legitimacy in Alternative Dispute Resolution’ (2011) 2011 J Disp Resol 1, 8.

24 Timothy S Durst and Cheryl L Mann 'Behind Closed Doors: Closing the Courtroom in Trade Secrets Cases’ (2000) 8 Tex Intell Prop LJ 355, 356. 
beyond the scope of what is necessary to establish their case or the actual misappropriation. Accordingly, secret information which was not infringed could be jeopardized. By the same token, a defendant defending himself against an owner's claim may be forced to disclose and identify trade secrets under his possession to prove that they vary from those owned by the owner or that the trade secrets were acquired independently. In such a situation, the defendant endangers his own trade secrets by disclosing them to an ill-intentioned plaintiff. Because arbitration and mediation are by definition private, the confidentiality of such information typically is easier to ensure than in public court adjudication. ${ }^{25}$ The arbitrator is under an obligation not to disclose confidential information involved in the dispute. ${ }^{26}$ In arbitration and mediation, even the existence of the dispute can remain confidential if that is the parties' preference.

Intellectual property disputes often arise between parties that have or are likely to have an on-going business relationship. For example, parties to the dispute may have a licence relationship in existence prior to the dispute. ${ }^{27}$ In such a situation, the parties may appreciate the opportunity to use a mechanism that is much less formal and aggressive than litigation. ${ }^{28}$ This method allows the parties to work out their differences without souring their relationship or ability to work together in the future.

\section{The status of ADR use for IP disputes in Jordan}

The use of ADR to settle disputes in Jordan is still lagging behind many other jurisdictions. ${ }^{29}$ Traditionally, ADR has not played a significant role in intellectual property disputes in Jordan, which have consumed extensive court time. ${ }^{30}$ There are two different sets of reasons that contribute to this state of affairs. First,

25 Danny Ciraco 'Forget the Mechanics and Bring in the Gardeners' (2000) 9 U Balt Intell Prop LJ 47, 76.

26 International organizations employing ADR offer strict rules and procedures with respect to confidentiality. See eg Arbitration Rules of the World Intellectual Property Organization which detail the nature of confidential information, rights and obligations of parties, and role of the tribunal. See WIPO Arbitration Rules, Arts 52, 73-76.

27 Scott H Blackman and Rebecca M McNeill 'Alternative Dispute Resolution in Commercial Intellectual Property Disputes' (1998) 47 The American University Law Review 1709, 1726; Kevin M Lemley 'I'll Make Him an Offer He Can't Refuse: A Proposed Model for Alternative Dispute Resolution in Intellectual Property Disputes' (2004) 37 Akron L Rev 287, 305.

28 Ibid, 311-13.

29 Guiseppe De Palo and Linda Costabile 'Promotion of International Commercial Arbitration and other Alternative Dispute Resolution Techniques in Ten Southern Mediterranean Countries' (2007) 7 Cardozo Journal of Conflict Resolution 303, 313 (few arbitrations probably occur in Jordan because its society is more civil-service oriented than businessminded). there are legal hurdles in that intellectual property laws lack specific statutory language that would guarantee the arbitrability of copyright, trade mark and patent disputes. Second, there are extra-legal hurdles relating to the context of intellectual property disputes because they do not arise in a contractual relationship, Jordanian intellectual property laws are recent or Jordan's ADR mechanisms are still in their early stages of development.

\section{Legal hurdles}

The question as to what matters can be arbitrated becomes problematic when one considers intellectual property rights. ${ }^{31}$ Some hold the view that all issues involving intellectual property rights in Jordan are arbitrable. ${ }^{32}$ However, there is evidence suggesting that matters relating to infringement, validity and other issues are not arbitrable. In contrast to that view, as will be shown below, courts and State administrative agencies in Jordan have exclusive jurisdiction to hear certain intellectual property cases.

There is no specific statutory language in Jordan's intellectual property laws guaranteeing the arbitrability of copyright, trade mark and patent cases. Jordan's intellectual property laws favour courts rather than private arbitrators to resolve disputes concerning intellectual property rights. This view is evidenced by the Copyright Law which provides that, in case of the suspicion that an infringement is being committed by a business which prints, reproduces, produces or distributes works, the court can be petitioned to investigate the case. ${ }^{33}$ The copyright, patent and trade mark laws provide for penal sanctions in case of infringement. ${ }^{34}$ These penalties arising from illegal acts are not arbitrable. Compulsory licences are excluded from arbitration by law. ${ }^{35}$ Under Jordan's intellectual property law, there is

30 The number of intellectual property cases decided by Jordanian courts has grown exponentially. For example, in the year 2000 courts decided only 10 cases, compared with 584 in 2011 . This state of affairs has strained the judicial system. See The Jordanian Judicial Council, above, n 20, 99.

31 The question of whether a particular subject matter is arbitrable is often referred to as a question of "objective arbitrability": M.A. Smith, M. Couste, T. Hield, R. Jarvis, M. Kochupillai, B. Leon. J.C. Rasser, M. Sakamoto, A. Shaughnessy, and J. Branch, Arbitration of Patent Infringement and Validity Issues Worldwide, 19 Harv. J. Law \& Tec 299, 305 (2006).

32 See L.M. Daradkeh and Ala Elden Kasawneh, The Capability of Intellectual Property Disputes of Being Settled by ADR: Theoretical and Practical Approach under Jordanian Law, 4 International Journal of Intellectual Property Management 283, 286 (2011).

33 Copyright Law, supra note 17, art. 36.

34 Patent Law, supra note 17, art. 32; Copyright Law, supra note 17, arts. 51, 52.

35 Patent Law, supra note 17, arts. 22, 26. 
no explicit distinction between invalidity of intellectual property rights raised as a defence against an infringement claim and an attempt to revoke the entire intellectual property right, in which case only the former may be arbitrable. ${ }^{36}$ Moreover, issues of lapse of protection and cancellation of a registered intellectual property right fall within the jurisdiction of the High Court of Justice, Court of First Instance or the Patents Registrar. ${ }^{37}$ These issues must be entered into a public register and inherently involve public interest. Therefore, the ultimate authority for determining intellectual property rights lies in the State authority or judiciary.

While Jordan's intellectual property laws are silent on the arbitrability of intellectual property rights, the Arbitration Law widens the scope of arbitration. Arbitration can cover any legal dispute whatever the legal nature of the relationship which is the subject matter of the dispute. The disputing parties can refer any dispute whether civil or commercial, contractual or non-contractual, to arbitration. ${ }^{38}$ However, arbitration is not permitted in matters that cannot be conciliated. $^{39}$ The Arbitration Law does not clarify or provide examples of what matters cannot be conciliated, but these matters likely include crimes, divorce, bankruptcy and other matters relating to public order.

The Jordanian Arbitration Law does not have specific provisions for intellectual property disputes. In principle, therefore, there is no legal obstacle that bars an arbitral panel from ruling on intellectual property disputes. Private parties can contract to settle their disputes through arbitration. Nevertheless, it remains unclear whether all issues involving intellectual property rights, including the validity of intellectual property or ownership of the rights, are arbitrable. ${ }^{40}$ One can assume that disputes relating to contractual rights and obligations, such as amounts of royalty paid in a licence agreement, scope of licence and guarantees, are arbitrable. This assump- tion is based on the fact that these are purely private issues pertaining to the interpretation of an agreement, and they are governed by a licensing agreement, rather than public interest issues, such as validity and revocation questions, that fall within the jurisdiction of the Patents Registrar of the Ministry of Industry and Trade, the National Library Department for copyright or Registrar of Trade Marks. However, it is unclear if the award issued by an arbitrator is final and binding only between the parties to the arbitration or it will have effect on any other person. ${ }^{41}$ Also, an open question arises as to whether intellectual property issues can be subject to arbitration absent an underlying contractual arrangement.

At any rate, Jordanian courts have not ruled on what intellectual property issues can be arbitrated. Additionally, there is no data in Jordan that would provide settlement rates or any other data on intellectual property disputes resolved through $\mathrm{ADR}^{42}$ It remains unknown whether courts in Jordan will permit intellectual property disputes to be arbitrated, and whether courts will interpret arbitration clauses to encompass some or all intellectual property claims.

Many Jordanians prefer to use the courts because this allows them to retain the right to appeal a judicial decision if the court misapplies the law or makes some other mistake. The Jordanian Arbitration Law reflects this preference by excluding appellate review. ${ }^{43}$ An arbitral award is final and binding on the parties. Nevertheless, the absence of formal appeal does not mean that arbitral decisions are never reviewed. Such review does exist, but it is limited to correcting gross errors. For example, the Jordanian Arbitration Law allows an award to be set aside if the panel acted beyond its authority. ${ }^{44}$ In sum, the Jordanian Arbitration Law authorizes judicial review of arbitral decisions and thus an arbitration award can be vacated but in narrow circumstances.
36 See for example the Patent Law, supra note 17, art. 30.

37 Patent Law, supra note 17, art. 30; Copyright Law, supra note 17, art. 50.

38 Arbitration Law of Jordan No. 31 of 2001, art. 3, Official Gazette No. 4496 (2001). The different schools of Islamic legal thought also have different opinions regarding the type of matters that may be arbitrated. The Hanafis believe that arbitration should only be utilized when dealing with the private rights of parties in commercial or proprietary matters. The Hanbalis and Shafi'is allow arbitration in all commercial cases, but not in any other cases. The Malikis, on the other hand, allow arbitration to be applied to non-commercial cases as well. However, all four schools of Islamic thought agree that arbitration cannot be used in those disputes which a judge alone is competent to decide. See Khalid Rashid, Alternative Dispute Resolution in the Context of Islamic Law, 8 Vindobona J. Int'l Com. L. 95, 104 (2004).

39 Id. art. 9.
40 In contrast, the U.S. Patent Act authorizes voluntary, binding arbitration of patent validity and infringement issues: see U.S. Patent Act, 35 U.S.C. Section 294(a).

41 Decisions made the Patent Act are not binding on anyone other than the parties to the arbitration: U.S. Patent Act, 35 U.S.C. Section 294(a); William Grantham, The Arbitrability of International Intellectual Property Disputes, 14 Berkely J. Int'l L. 173 (1996).

42 The number of cases settled through court-administered mediation in 2011 reached 1,395 cases. Those cases involved labour, insurance, lease, and banking disputes. See The Jordanian Judicial Council, above, n 20, 99-103. No figures are available as to the number of intellectual property cases settled through ADR whether court-sponsored or otherwise.

43 Arbitration Law of Jordan, supra note 38, Art 48.

44 Ibid, Art 49. 


\section{Extralegal hurdles}

In addition to the legal barriers hindering the use of ADR to settle intellectual property disputes in Jordan, there are other reasons why ADR mechanisms are not as commonly used as one might hope. In terms of generating intellectual property, Jordan and other Arab countries lag behind the rest of the world. The number of patents registered by Arab countries in the US is much lower than that of other countries. For example, between 1980 and 2000, Israel registered 7652 patents in the USA and South Korea registered 16328 patents in the USA. Within the same 20-year period, Saudi Arabia led the Arab world in registering patents in the USA with 171. Egypt had 77, Kuwait 52, the United Arab Emirates 32, Syria 20 and Jordan $15 .{ }^{45}$ In view of the disparity in the number of registered patents and other intellectual property products between Arab countries and other countries, some doubts can be raised as to the utility of using ADR by Arab individuals to settle any disputes.

Intellectual property disputes rarely arise in a contractual relationship because disputes generally arise when an individual or a company allegedly violates intellectual property rights of others through unauthorized use, copying or imitation. ${ }^{46}$ In these circumstances, the authority to grant immediate injunctive relief and impose criminal sanctions is vested in the State. The Court of First Instance may issue an order for the cessation of the infringement of the work, confiscation of the work, confiscation of the revenues or destruction of the reproductions of the work or the copies made of it. ${ }^{47}$ Parties seeking injunctive relief to prevent copyright, patent, trade mark infringement or trade secret disclosure have to wait until an arbitration panel is formed, which can take some time-especially if the parties employ frivolous delaying tactics. ${ }^{48}$ The right holders are thus inclined to pursue their rights through courts, which are readily available to issue injunctive relief.

45 Raj Bhala 'Discovering Great Opportunity in the Midst of Great Crisis: Building International Legal Frameworks for a Higher Standard of Living: Doha Round Betrayals' (2010) 24 Emory Int'l L Rev 147, 180.

46 Robert M Hirning 'Contributory and Vicarious Copyright Infringement in Computer Software: Harming One Form of Intellectual Property by Protecting Another' (2006) 6(1) Chicago-Kent J Intell Prop 10, 21-23.

47 Copyright Law of Jordan, above, n 16, Arts 46, 47.

48 D Alan Redfern 'Arbitration and the Courts: Interim Measures of Protection-Is the Tide about to Turn?' (1995) 30 Tex Int'l LJ 71, 83. See also Alain Fré 'Delaying Tactics in Arbitration' (2005) 594 Disputes Resolution Journal 6-7 (2005).

49 Martin A Frey 'Does ADR Offer Second Class Justice?' (2001) 36 Tulsa LJ $727,734-35$. (In mediation, the third party is neutral and is invited to participate in the process. Mediation has been a private process as the parties hire and pay the mediator. In arbitration, the disputants come before a third party, the arbitrator.)

50 Jordanian judges also lack sufficient understanding of the complicated legal and technological issues involving intellectual property cases: Tabbaa
Availability of expertise is another reason affecting the use of ADR to settle intellectual property disputes. In arbitration and other ADR mechanisms, parties are able to select the arbitrators and mediators who will hear and consider their disputes. ${ }^{49}$ Intellectual property disputes may involve complex technologies or difficult issues of valuation; thus, the lack of qualified Jordanian experts/arbitrators in the domain of intellectual property makes proceedings less efficient and the outcomes less acceptable. ${ }^{50}$ Jordan could attempt to address this lack of expertise by establishing a centre to train staff-judges and arbitrators-on complex infringement cases and other intellectual property issues. Indeed, the Arab Intellectual Property Mediation and Arbitration Society was formed in 2003 in Jordan to handle intellectual property arbitration. ${ }^{51}$ Before 2003, Jordan had no institutional framework for arbitrating intellectual property disputes. The Arab Intellectual Property Mediation and Arbitration Society is still a young institution that needs time to develop. In the meantime, Jordanian parties involved in intellectual property cases can enlist well-known institutions outside Jordan to resolve their disputes through arbitration and other ADR mechanism which provide services such as selecting qualified arbitrators from a roster. ${ }^{52}$

Many of Jordan's intellectual property laws are relatively new. The laws were recently modified and enacted only recently on the eve of Jordan's accession to the World Trade Organization (WTO). In fact, Jordan had been on the US Watch List for quite some time, where the USA has been closely watching Jordan's intellectual property regime. The situation worsened when there was discussion in 1998 on whether Jordan would be targeted with trade sanctions under Special 301 of the 1988 Omnibus Trade and Competitiveness Act for failing to adequately protect US copyrights, patents and trade marks. Compliance with the Agree-

and Partners Concept Paper on Developing a Sustainable IP Judicial Training Program (United States Agency for International Development, Washington, DC 2007) 5 (Although the public is confident when it comes to judicial fairness and integrity, this confidence falls short when assessing judges' technical capacity and ability to deal with novel laws and issues such as IPR. Judicial enforcement in IP cases in Jordan remains poor and courts take years to settle conflicts and often provide remedies wholly-inadequate to the goal of deterrence of criminal acts).

51 Wuwei-Hua 'International Arbitration of Patent Disputes' (2010-11) $10 \mathrm{~J}$ Marshall Rev Intell Prop L 384, 389. The activities of the Arab Intellectual Property Mediation and Arbitration Society include training courses, publications, and using ADR means to settle intellectual property disputes: Arab Intellectual Property Mediation and Arbitration Society 'The Activities of AIPMAS' AIPMAS.org.

52 Mladen Singer 'Commercial Arbitration as a Means for Resolving Industrial Property and Transfer of Technology Disputes' (1996) 3 Croat Arbit Yearbook 107, 116 (citing the American Arbitration Association and WIPO Arbitration and Mediation Center). 
ment on Trade-Related Aspects of Intellectual Property Rights (TRIPS) and being taken off the US watch list of Special 301 helped Jordan accede to the WTO. ${ }^{53}$

In light of its intellectual property record, Jordan needs to demonstrate publicly that it effectively enforces intellectual property rights. Efforts by the Jordanian government to protect foreign intellectual property interests in Jordan have made front-page news. ${ }^{54}$ Through this kind of publicity, Jordan sends a deterrent message to potential infringing third parties. Moreover, many lawyers in Jordan automatically resort to litigation to resolve intellectual property issues. ${ }^{55}$ The choice to litigate may also be due to the lack of familiarity with ADR methods. Jordan's laws and practices thus seem to encourage intellectual property holders to pursue violators through public judicial vindication.

Jordanian ADR is still in its early stages of development. Similar to other countries, ADR-court-administered mediation mechanisms have recently been adopted in Jordan. ${ }^{56}$ For example, the Mediation Law for Settling Civil Disputes ('Mediation Law') was enacted in $2006 .{ }^{57}$ Although the title of the law is misleading, it is interesting to note that commercial disputes are included in this law. ${ }^{58}$ There is therefore no doubt that arbitrable intellectual property disputes can be also resolved by mediation.

By virtue of the Mediation Law, a 'Mediation Directorate' is established and composed of a number of judges from both the Court of Peace and Court of First

53 Gary G Yerkey 'U.S., Jordan Hold Talks in Effort to Avoid Sanctions over IP Protection' (1998) 15 Int'l Trade Rep (BNA) 661; Gary G Yerkey 'U.S. Removes Jordan from "Watch List" of Special 301 Nations Failing to Protect IP’ (1999) 16 Int'l Trade Rep (BNA) 2047.

54 Suha Ma'ayeh 'Improved IPR Enforcement Gets Mixed Reviews' Jordan Times (United States Embassy Press Release 10 May 2001) 10; 'Jordan Police Intensify Action Against Piracy’ Jordan Times (15 May 2001) 18; United States Embassy 'U.S. Embassy Donates Two Vehicles to the Jordan Standards and Metrology Organization' (March 2011) (JSMO will use these vehicles to inspect imported goods to ensure their compliance with Jordanian standards and to conduct market surveillance to identify and confiscate counterfeit items).

55 Telephone Interview with Mazen Irsheidat, President of Jordan Bar Association (12 January 2012).

56 In 2006, the US Court of Appeals for the Federal Circuit, which deals with the majority of intellectual property appellate disputes, enacted a mandatory non-fee mediation program for parties seeking to appeal court decisions of intellectual property disputes: WL Dean 'Let's Make a Deal: Negotiating Resolution of Intellectual Property Disputes Through Mandatory Mediation at the Federal Circuit' (2007) 6 John Marshall Review of Intellectual Property Law 365.

57 The Mediation Law for Settling Civil Disputes No 37, Official Gazette No 4595 (2006).

58 Ibid, Art 3.

59 Ibid, Art 2.b.

60 Ibid, Art 2.c.

61 Lynn Cole, Nancy Fashho and Ahmad M Yakzan 'Jordan Leads Arab Middle East in Mediation' (2008) Association of Conflict Resolution: International Section Newsletter 9.
Instance. ${ }^{59}$ In addition to these judges, the Minister of Justice may nominate 'Special Mediators' and private mediators approved by the court to settle referred disputes. ${ }^{60}$ These 'Special Mediators' are likely to be former elder statesmen or high-ranking judges held in high societal esteem. ${ }^{61}$ Thus, this law provides for three types of mediators as a voluntary alternative to litigation: judges, special mediators and private mediators. The principal objectives of the mediation requirement, which the Mediation Law hopes to attain, are the reduction to the inflow of new cases which would alleviate the number of cases burdening the court system, in particular small claims, while at the same time granting parties a simpler and faster means of dispute resolution with clearly defined costs and timeframes.

Historically, arbitration, the principal form of alternative dispute resolution, has long been viewed sceptically and with hostility in the Arab world. ${ }^{62}$ Western arbitrators, in Aramco and Abu Dhabi arbitral awards, rendered decisions that exclude the Arab countries' national legal systems in a humiliating manner. ${ }^{63}$ Arab countries are concerned that if ADR methods are used to settle intellectual property disputes, it will lead to the domination of Western arbitrators and mediators over Arab arbitrators and mediators. ${ }^{64}$ Exclusion of certain laws or rules for reasons of bias is no longer the case. ${ }^{65}$ Although these historical arbitral awards are a thing of the past, their repetition poses only a remote possibility. Today, ADR does not presuppose any particular

62 Charles N Brower and Jeremy K Sharpe 'International Arbitration and the Islamic World: The Third Phase' (2003) 97American Journal of International Law 643 (the legal community throughout the Arab world is still manifesting its hostility to transnational arbitration mainly as a result of the great publicity devoted to the criticism of certain unfortunate arbitral awards).

63 Alexander Orakhelashvili The Position of the Individual in International Law' (2001) 31 Cal W Int'l LJ 241, 258-59 (In Abu-Dhabi Oil

Arbitration, the tribunal held that no domestic law can reasonably be said to exist. The sheikh administers a purely discretionary justice with assistance of the Qur'an; and it would be fanciful to suggest that in this very primitive region there is any settled body of legal principles applicable to the construction of modern commercial instruments. In the Aramco arbitration, after it was ascertained that the law of the host State did not contain the rules on concessionary contracts, the Aramco tribunal referred to general principles of law, customs and practice in the oil business and the notions of pure jurisprudence).

64 Abdel Hamid El Ahdeb Role of Arbitration in Dissolving Intellectual Property Disputes (2009) 12, available at shiac.com (in Arabic); Samir Saleh 'Commercial Arbitration in the Middle East: A Study' in Shari'a and Statute Law (Graham \& Trotman London 1984) 1 (stating that Arab parties are usually reluctant to arbitrate in a foreign state and under foreign rules of procedure).

65 Amr A Shalakany 'Arbitration and the Third World: A Plea for Reassessing Bias under the Specter of Neoliberalism' (2000) 41 Harv Int'l LJ 419, 448-57 (2000). 
procedure or method of proceeding; to the contrary, Arab parties view $\mathrm{ADR}$ as neutral means to settle disputes.

\section{ADR as the way forward}

The overall picture of using arbitration and other ADR methods to settle intellectual property disputes in Jordan is still emerging. There is a plethora of new issues. Jordan did not extend arbitration expressly to intellectual property disputes. Jordan's intellectual property laws contain no specific statutory language guaranteeing the arbitrability of copyright, trade mark or patent cases. Further, Jordanian Arbitration Law makes no specific provisions for intellectual property disputes.

Patent rights are property rights created by a sovereign entity and recorded in the Ministry of Industry and Trade's register. It remains unclear if all issues involving intellectual property rights, including the validity of intellectual property or the ownership of intellectual property rights or extent of the rights granted, are arbitrable. There is no court precedent in Jordan that would provide guidance in determining the extent of arbitrability of intellectual property disputes.

Nevertheless, private parties may contractually agree to settle their disputes through arbitration. Disputes such as those arising from agreements entered between the parties for use, transfer or development of intellectual property products are considered arbitrable.

Laws in Jordan should be modified by making provisions allowing expressly for intellectual property disputes to be resolved through arbitration and other means. With respect to arbitrability, issues pertaining to grant, validity and infringement should be kept out of the purview of arbitration. Issues that arise in agreements between private parties, such as those related to licensing, may be resolved through arbitration. Arbitration and other ADR means should be time-limited, confidential and assessed by experts in the relevant field.

Intellectual property disputes generally involve lengthy proceedings, tremendously costly and resource demanding, and provide one-sided outcomes. Arbitration allows parties to bypass the backlogged judicial system in Jordan. Arbitration can start immediately and parties can control the arbitration process. Flexibility exists in selecting arbitrators and procedures thus reducing time and saving money for the parties involved. Given the benefits, intellectual property practitioners in Jordan should no longer turn automatically to the court system to resolve intellectual property disputes. Jordanian authorities should establish programs to encourage enhancement of expertise in intellectual property cases among judges and lawyers.

Arbitration and other ADR mechanisms should be available for resolving intellectual property disputes whether domestic or international. Parties have many options at their disposal to settle the dispute and choosing a specific option depends on the particulars of the case and the type of relationship between the parties. Using arbitration and other ADR mechanisms to settle intellectual property disputes in Jordan is a novel concept. However, as intellectual property disputes become more common and the international nature of disputes increases, the demand for arbitration and other ADR mechanisms in Jordan will gain importance. 